\title{
ESTADO LAICO E INTERFERÊNCIA RELIGIOSA
}

\author{
SECULAR STATE AND RELIGIOS INTERFERENCE
}

\author{
ALESSANDRO PINZANI \\ (Universidade Federal de Santa Catarina)
}

\begin{abstract}
RESUMO
$\mathrm{O}$ artigo analisa diferentes discursos que, neste momento, estão sendo formulados sobre a religião na esfera pública. Não se falará nele da religião ou das religiões, mas da maneira na qual esses temas são percebidos e discutidos na opinião pública ocidental, em particular européia, pois essa discussão tem algo relevante para a discussão sobre o papel da religião na sociedade brasileira. Serão considerados três discursos que serão denominados respectivamente de (1) "determinismo cultural", (2) "anti-religiosidade seletiva" e (3) "laicismo estatal". A intenção do artigo é apontar para os erros lógicos e categoriais e para as incoerências presentes nesses discursos que dominam o atual debate sobre o lugar da religião em geral e do Islã em particular nas sociedades ocidentais.
\end{abstract}

Palavras-chave: Religião. Estado laico. Intolerância religiosa. Neutralidade do Estado.

\begin{abstract}
The paper analyzes different discourses that, at present, are being used when talking about religion in the public sphere. It shall not discuss religion or religions, but the way in which these themes are perceived and discussed in Western public opinion, particularly in Europe, since this debate can be relevant for the discussion on the role of religion in Brazilian society. The paper shall analyze three discourses, which shall be called respectively (1) "cultural determinism", (2) "selective anti-religiosity" and (3) "State laicism". It aims at pointing out the logical and categorical mistakes and the incoherencies in these discourses, which dominate the present debate on the role of religion in general and of Islam in particular in Western societies.
\end{abstract}

Key-words: Religion. Secular State. Religious Intolerance. State Neutrality.

Os acontecimentos recentes de Paris e Copenhagen, acompanhados pelo surgimento do chamado Estado Islâmico no Oriente Médio, deram novo ímpeto ao debate sobre fundamentalismo religioso e, mais em geral, sobre o papel da religião na política. ${ }^{1}$ Ao mesmo tempo, se desfizeram as ilusões de que esse papel fosse unicamente positivo ou de que fosse possível uma convivência pacífica entre posições secularizadas, por um lado, e posições ainda ancoradas a visões religiosas arcaicas e intransigentes, pelo outro. O fundamentalismo religioso ganhou nova força, não somente no mundo islâmico, ou entre os imigrados muçulmanos da Europa, ou na península indiana, onde ele nunca saiu de moda, por assim dizer, ${ }^{2}$ mas também entre os judeus ortodoxos de Israel ou em certas seitas evangélicas na América Latina, particularmente no Brasil, país no qual a laicidade do Estado nunca passou de um princípio abstrato escassamente respeitado, começando pela presença invasiva de 
símbolos religiosos nos espaços públicos (como no caso da exposição de crucifixos nos tribunais ou nas escolas, da presença de bispos católicos e, recentemente, evangélicos nas cerimônias públicas - até chegar ao lema "Deus seja louvado" impresso nas notas da moeda oficial, numa estranha combinação de Deus e Mamona). ${ }^{3}$ Isso sem mencionar os brutais episódios de violência física dos quais são vítimas os terreiros e os fieis de Umbanda e Candomblé pela mão de fundamentalistas evangélicos (inclusive de traficantes evangélicos) ${ }^{4}$ e lembrando que, segundo várias pesquisas, os ateus são o grupo mais rejeitado e odiado pelos brasileiros (mais do que traficantes ou do que políticos corruptos). ${ }^{5} \mathrm{~A}$ meu ver, estamos assistindo a um retrocesso impressionante no que diz respeito aos princípios de tolerância e aceitação da diversidade proclamados pelo Esclarecimento e atacados veementemente por fundamentalistas religiosos de vários tipos, por um lado, e, por outro, pelos que acusam o Iluminismo de não passar de uma expressão de imperialismo cultural, a ponto de que indignar-se pelos crimes praticados em nome de Alá ou de Cristo pelos seus seguidores mais fanáticos se tornou por sua vez expressão de arrogância cultural e de racismo "tipicamente" europeus ou até de islamofobia e ódio anti-cristão.

Neste contexto, o que a filosofia pode dizer que não tenha já sido dito por Spinoza, Locke ou Voltaire? De nada adianta repetir mais uma vez os argumentos que sustentam os mencionados princípios de tolerância, de aceitação da diversidade e de liberdade de crença para quem não quer ouvi-los ou não tem escrúpulos em fazer deles um uso (melhor seria dizer: um abuso) instrumental à própria causa, invocando-os quando se trata de justificar o próprio presumido direito de discriminar os que adotam crenças ou estilos de vida que não correspondem à própria visão religiosa. Quanto aos moderados entre os religiosos, que, por enquanto, representam ainda uma maioria, receio que sua posição esteja destinada a tornar-se cada vez mais complicada, perante o acirramento do conflito entre fundamentalistas e secularizados, e que acabem tendo que decidir-se para um dos dois lados, isso é: ou deixar de ser moderados, assumindo a visão fundamentalista, ou permanecer em sua visão moderada, tornando-se vítimas potenciais dos fundamentalistas, como está acontecendo no Estado Islâmico, no qual os fanáticos não distinguem entre infiéis, pecadores e fieis excessivamente tíbios, quando se trata de degolar, apedrejar ou em geral condenar a morte.

No presente texto, contudo, não analisarei o discurso religioso em si, mas os diferentes discursos que, neste momento, estão sendo formulados sobre ele. Em outras palavras, não falarei da religião ou das religiões, mas da maneira na qual esses temas são percebidos e discutidos na opinião pública ocidental, em particular européia, pois, em minha opinião, essa 
discussão tem algo relevante para a discussão sobre o papel da religião na sociedade brasileira. Em particular, me ocuparei de três discursos que denominarei respectivamente de (1) “determinismo cultural", (2) "anti-religiosidade seletiva" e (3) "laicismo estatal”. Minha intenção é apontar para os erros lógicos e categoriais e para as incoerências presentes nesses discursos que, a meu ver, dominam o atual debate sobre o lugar da religião em geral e do Islã em particular nas sociedades ocidentais.

Começarei, então, pelo discurso que denominei de "determinismo cultural" e que é proposto principalmente pelos autores que acusam de "imperialismo cultural" os ocidentais em geral e, em particular, os críticos do fundamentalismo religioso islâmico. A lista é comprida e inclui pensadores destacados como Martha Nussbaum ${ }^{6}$ e autores menos conhecidos. Nem todos os argumentos usados por esses autores são igualmente sofisticados. Os mais toscos são aqueles que seguem por sua vez um tipo de fundamentalismo ideológico, cujo dogma central é que a causa de tudo o que tem de mal no mundo são os europeus em geral e o Iluminismo em particular. Com certeza, esta posição possui certa plausibilidade, mas, sem querer minimizar as inegáveis responsabilidades históricas de alguns países europeus em criar a atual situação política do Oriente Médio (espero que ninguém queira seriamente culpar, por ex., a Eslovênia ou a Eslováquia pelos problemas internos da Síria), é preciso ter uma visão um pouco mais sofisticada das coisas e, sobretudo, uma visão menos racista - pois, como veremos, racistas são também os que defendem ou pelo menos dizem compreender a ação dos assassinos de Paris e Copenhagen.

Comecemos, então, justamente por este ponto. A reação popular ao atentado na sede de Charlie Hebdo (doravante $\mathrm{CH}$ ) foi, como era de se esperar, muito emotiva, com os lápis levantados, as escritas "Je suis Charlie" etc. Contudo, gostaria de lembrar que, apesar de as razões do atentado e suas raízes no fundamentalismo islâmico terem sido evidentes desde o começo, não houve praticamente ações violentas contra os muçulmanos que vivem na França, fora algumas tentativas bastante amadoras e fracassadas de atentados com coquetéis molotov contra algumas mesquitas em cidades periféricas. Não obstante isso, imediatamente se agitou o espantalho da islamofobia que estaria tomando conta da opinião pública europeia e da ameaça à integridade física dos muçulmanos na Europa. O simples fato de solidarizar com as vítimas do primeiro atentado de Paris, ou seja, os desenhistas e jornalistas do $\mathrm{CH}$, foi descrito por alguns comentadores como expressão de ódio ao Islã, uma vez que esse jornal se caracterizava pela sátira pesada (e, admitamos francamente, de bastante mau gosto) contra Maomé e contra os fundamentalistas. Não pretendo certamente negar a existência de certo anti-islamismo no debate europeu ou até de uma aberta islamofobia em alguns setores da 
sociedade e do mundo político europeu e norte-americano, pois se trata de fatos inegáveis, mas - como já disse - gostaria de esboçar um quadro um pouco mais matizado da situação. Os autores que levantam a acusação de islamofobia não são por sua vez isentos de preconceitos e até de racismo. Se não, vejamos.

Em abril de 2015, em ocasião da proposta do PEN Club (a mais importante associação internacional de escritores) de atribuir um prêmio ao $\mathrm{CH}$, seis escritores, membros do próprio PEN Club, protestaram com argumentos como os seguintes: $\mathrm{O} C H$ teria dado prova de "intolerância cultural", ao promover "uma espécie de visão secular forçada" e o $P E N$ demonstraria uma "aparente cegueira perante a arrogância cultural da nação francesa, que não reconhece sua obrigação moral em relação a um segmento amplo e desempoderado [disempowered] de sua população". ${ }^{7}$ É irônico que neste caso numa mesma sentença se fale em arrogância cultural e se acuse dela uma inteira nação, pois uma acusação tão genérica e drástica demonstra justamente a arrogância de quem a formula - embora neste caso não se trate tanto de arrogância cultural, quanto de arrogância moral e, afinal, de racismo, pois se trata de atribuir um traço negativo a uma população inteira (os franceses) com base no comportamento de um grupo de indivíduos que a ela pertencem (os jornalistas do $\mathrm{CH}$ ). Estaríamos aqui perante uma expressão de francofobia? Pois se é expressão de islamofobia atribuir a todos os muçulmanos os traços negativos dos terroristas fundamentalistas, o mesmo deveria se aplicar para quem atribui a todos os franceses a arrogância cultural de alguns deles - admitindo que os jornalistas do $\mathrm{CH}$ se tivessem manchado desta culpa, o que na realidade deveria ser demonstrado. Cabe lembrar, neste sentido, que $C H$ tinha como alvo de sua sátira não somente o Islã, mas todas as religiões e todas as correntes políticas, a direita como a esquerda, ${ }^{8}$ e que, portanto, atribuir arrogância cultural a $\mathrm{CH}$ não é correto, se com isso se entende que seus jornalistas se achavam culturalmente superiores aos muçulmanos ou aos imigrados. Claro que qualquer escritor ou desenhista satírico pode ser acusado de considerarse de certa maneira superior àquele que é objeto de sua sátira: qualquer desenhista que faça uma caricatura de um político corrupto poderia ser acusado de arrogância moral. Mas essa acusação pode ser utilizada contra os próprios acusadores. Por ex. os mencionados escritores que contestaram o prêmio do $P E N$ para $C H$ podem ser acusados de se acharem moralmente superiores tanto aos jornalistas do $C H$ como ao júri do PEN. Por isso, antes de lançar acusações tão genéricas e, finalmente, inúteis, pois aplicáveis a qualquer pessoa que expressa uma crítica qualquer em relação a um assunto qualquer, seria importante levar em conta o contexto - por ex. a história do $\mathrm{CH}$ e a pluralidade de temas e de pessoas que foram objetos 
da sua sátira. Esse cuidado parece faltar no caso dos que acusam indiscriminadamente o jornal e seus defensores de arrogância cultural, islamofobia ou até racismo.

Um erro pior é praticado por aqueles que, se não justificam, pelo menos explicam o assassinato dos jornalistas apontando para a sensibilidade religiosa dos assassinos. O argumento usado é de que as caricaturas de Maomé, ou melhor: o simples fato de representar o Profeta, constituiria aos olhos dos muçulmanos uma ofensa inaceitável que os levaria inevitavelmente a reagir veemente e até violentamente. Não consigo imaginar argumento mais racista e islamófobo. O que se está afirmando aqui é que os muçulmanos não são sujeitos morais autônomos, capazes de refletir antes de agir, avaliando, por exemplo, a proporcionalidade entre a ofensa recebida e sua reação, mas indivíduos que reagem a qualquer ofensa automaticamente de forma violenta, seguindo um reflexo condicionado, como os cachorros de Pavlov, na incapacidade total de conter-se ou de perdoar o ofensor. Ao mesmo tempo, esse argumento é expressão de uma enorme arrogância cultural, uma vez que nega aos muçulmanos aquela autonomia para decidir reagir de maneira pacífica e refletida que se atribui aos europeus não muçulmanos, que aos olhos desses autores não merecem a mesma justificativa quando reagem de forma espontânea às ações dos terroristas, por exemplo, organizando manifestações como em Paris ou usando o lema "Je suis Charlie", uma vez que tais respostas são consideradas expressão de intolerância, imperialismo cultural, islamofobia, etc. Nessa visão, os europeus não muçulmanos possuem evidentemente a capacidade de controlar completamente suas reações e, portanto, têm o dever de reprimir sua intolerância, enquanto os europeus muçulmanos não dispõem da mesma capacidade e, portanto, não podem ser considerados plenamente responsáveis pelas suas ações violentas. Confesso que não consigo entender essa lógica bizarra a não ser como expressão de arrogância cultural, moral e espiritual ou, na melhor das hipóteses, de paternalismo por parte dos que se servem desse argumento.

Nisso consiste, basicamente, o determinismo cultural: o simples fato de pertencer a certa cultura, neste caso, a uma cultura baseada sobre a religião islâmica, representaria para o indivíduo uma sina inescapável, que o torna mais ou menos capaz de agir de forma autônoma e refletida. Assim, seria de se esperar que um muçulmano se ofenda terrivelmente ao ver uma imagem de Maomé e que reaja de forma violenta. Na realidade, as culturas são mais ou menos porosas e tendem a modificar-se pelo contato com outras. Assim, os muçulmanos que moram na Europa não vivem necessariamente sua religiosidade da mesma maneira dos que moram nos países árabes, por exemplo. Por isso, frente três indivíduos que tomaram em armas e foram matar infiéis, milhões de muçulmanos franceses não se interessaram pela capa do $C H$ 
ou protestaram de forma absolutamente pacífica. A cultura não é um destino inevitável e a crença religiosa não implica num mecanismo determinista que torna o fiel um autômato cujo comportamento está já predeterminado pela sua fé, como parecem pensar os defensores do chamado multiculturalismo-mosaico, no qual as culturas vivem uma ao lado da outra, mas cada uma fechada em si mesma, como pedrinhas de um mosaico. ${ }^{9}$

Há ainda outro aspecto: Os críticos dos protestos pró- $\mathrm{CH}$ admoestam (justamente) a não cair no erro de generalizar, elevando os assassinos de $\mathrm{CH}$ a representantes do Islã tout court, mas acabam cometendo exatamente esse erro, quando tentam apresentá-los como representantes de um inteiro grupo social, a saber, os jovens imigrados de segunda ou terceira geração vítimas do racismo europeu. Ora, ou bem eles devem ser considerados tão somente como indivíduos e como tais responsabilizados; ou bem eles devem ser considerados como representantes de um grupo maior - e neste caso, não é tão simples assim excluir que eles representem os muçulmanos franceses em vez do que os jovens imigrados de segunda ou terceira geração.

O principal obstáculo para uma discussão ponderada e produtiva sobre o tema reside, a meu ver, justamente na tendência de ambas as partes (os islamófobos e os anti-islamófobos) a atribuir a inteiras categorias ou a grupos atos e atitudes que são, em primeiro lugar, de indivíduos. Se os atentados de Paris e Copenhague tivessem sido considerados como ações de indivíduos fanáticos ou até psicologicamente perturbados (como no caso de Breivik, o fundamentalista cristão norueguês que em 2011 matou 79 pessoas na ilha de Utøya, sem que isso levasse a uma discussão sobre o cristianismo) e não como ações de "muçulmanos" ou, alternativamente, de "imigrados de terceira geração", o debate que seguiu esses eventos teria tomado outro rumo. Apelar para a discriminação social, política, econômica e racial sofrida pelos imigrados de terceira geração, para explicar (embora não necessariamente para justificar) os atentados, é uma faca de dois gumes, já que dessa maneira se apresentam dois problemas: (1) ou bem se tenta encontrar em tal discriminação o fator que desencadeia e, portanto, explica o comportamento violento - mas, nesse caso, pelo seu caráter genérico, tal fator poderia explicar qualquer ação violenta ou crime (um assalto a um banco, um estupro, etc.), sem que se entenda a peculiaridade dos atentados; (2) ou bem se pretende vincular a discriminação sofrida à negação da identidade religiosa dos sujeitos discriminados - mas, assim, estaríamos perante mais um caso de determinismo cultural acompanhado por um "pavlovismo", que não deixa espaço para o arbítrio individual dos sujeitos discriminados. Sem contar que a discriminação social, econômica e política não é exclusiva dos imigrados 
muçulmanos, pois nos países europeus, inclusive na França, há muitos "autóctones" cristãos ou secularizados que são excluídos e marginalizados - entre eles os que acabam tornando-se neonazistas, por exemplo, embora dificilmente os que recorrem ao argumento da discriminação para explicar os atentados de Paris e Copenhague aceitariam explicar os atos de violência neonazista pela exclusão social e econômica de seus autores. Algo parecido vale para o argumento da discriminação racial, uma vez que dela são vítimas também imigrados africanos de religião cristã ou imigrados chineses, por exemplo, sem que isso seja considerado como um fator que explique ou até justifique eventuais atos de violência praticados por eles (aliás, cabe lembrar que não há registro de atentados terroristas por mão de imigrados desses

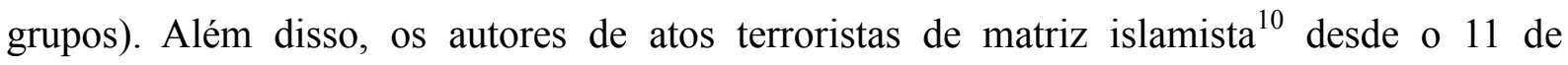
setembro de 2001 até Paris e Copenhague, passando pelas bombas de Madrid e de Londres e pelo assassinato de Theo van Gogh na Holanda, tinham biografias bem diferentes. Se os terroristas de Paris eram pequenos criminosos, já entrados várias vezes em conflito com lei, outros tinham formação superior, um trabalho e uma família, e eram bem inseridos econômica e socialmente em suas comunidades. No caso de Mohammed Atta, o mais conhecido entre os terroristas do 11 de setembro, e de alguns dos seus companheiros, não tinham sequer nascido na Europa e tinham ido para lá somente para realizar seus estudos superiores, desfrutando assim uma oportunidade que seu país de origem (no caso de Atta o Egito) não lhe oferecia.

Justamente para evitar considerar todos os muçulmanos responsáveis por esses atos, é necessário atribuir sua responsabilidade aos indivíduos que os praticaram. Ao fazer isso, contudo, é impossível esquecer que o que os levou a praticá-los foi, como eles mesmos sempre fizeram questão de deixar claro, um motivo religioso. Ninguém entre eles disse agir daquela maneira para vingar-se da discriminação e do racismo do qual ele pessoalmente teria sido vítima (no máximo mencionaram o colonialismo europeu e o imperialismo norteamericano que leva à presença militar norte-americana nos países árabes, mas esqueceram de dizer que tal presença acontece com o consenso dos governantes daqueles países, primeiramente da família real saudita). Os defensores da tese da discriminação como motivo dos atentados desconsideram isso e cometem um equívoco duplo. Por um lado, caem no mesmo erro do qual acusam seus adversários, fazendo assim o jogo deles, pois atribuem a responsabilidade de atos individuais a um grupo, quando direta ou indiretamente absolvem os terroristas em nome de uma discriminação sofrida pelos "muçulmanos" ou pelos "imigrados de terceira geração". Por outro lado, não conseguem entender a peculiaridade dos atentados, que consiste na sua motivação religiosa. Em minha opinião é preciso admitir que o motivo dos atentados foi religioso, por mais que suas causas possam ter sido de outro tipo. Somente a 
partir dessa admissão, podemos discutir se e em que medida o caráter religioso do motivo é relevante para entender esses atos, ou se podemos negligenciá-lo e ver neles simples crimes ou atos de mentes desequilibradas, como fazemos quando um adolescente vítima de bullying entra em sua escola com uma arma matando colegas ou quando um desempregado de longo prazo mata seus ex-empregadores. Somente reconhecendo que o motivo religioso é absolutamente relevante para entender os atentados em questão poderemos discutir sensatamente as causas (sociais, econômicas, políticas, etc.) que levam jovens muçulmanos europeus a tornarem-se fundamentalistas religiosos e não simples criminosos. ${ }^{11}$

Finalmente, antes de passar à segunda parte de meu artigo gostaria de mencionar um fato inquietante: os atentados contra desenhistas em Paris e Copenhagen foram seguidos por atentados contra judeus (no supermercado kosher em Paris e na sinagoga de Copenhagen). Esses não foram, contudo, objeto das mesmas atenções e discussões que os outros e seria interessante perguntar-se o porquê. Aliás, um tema do qual na Europa se fala muito pouco, se comparado àquele da islamofobia, é justamente o do crescente antissemitismo, que resultou nas últimas décadas em um aumento impressionante de atentados e atos de violência por parte de jovens muçulmanos contra judeus e instituições judaicas, particularmente na França ${ }^{12}$ (o que, naturalmente, não significa nem que os muçulmanos são antissemitas, nem que o atos antissemitas são todos praticados por muçulmanos). Pelo que sei, à frente dos inúmeros artigos dedicados à islamofobia européia em revistas acadêmicas como Philosophy and Social Criticism ou Costellations, não há nenhum falando do antissemitismo, como se a única forma de expressão de intolerância religiosa que merecesse ser discutida fosse aquela contra os muçulmanos (que, repito, quase nunca resultou em atos violentos, com uma única exceção relevante $)^{13}$ e não aquela que tem como alvo de ações violentas os judeus europeus, que vão de atentados incendiários contra sinagogas a homicídios extremamente brutais. Aliás, estranha constatar como, às vezes, os mesmos críticos que lamentam (com razão) o ódio e a intolerância contra os muçulmanos tendem às vezes a explicar a violência antissemita como reação à política violenta do governo de Israel nos territórios ocupados da Palestina, como se uma criança francesa de religião judaica pudesse ser considerada responsável pelas ações de um governo estrangeiro (Israel) - e isso constitui mais um caso de racismo por parte de certos presumidos "progressistas" que acabam atribuindo as culpas (inegáveis) do governo israelense a toda e qualquer pessoa de religião judaica no mundo, enquanto ao mesmo tempo se indignam, com toda razão, se alguém considera todo e qualquer muçulmano responsável pelas ações dos terroristas islâmicos. 
O segundo discurso que gostaria de mencionar é o da "antirreligiosidade seletiva", que se expressa muito bem no anti-islamismo de certos setores da sociedade européia. Caberia distinguir aqui duas questões que, mesmo relacionadas entre si, são diferentes, embora sejam frequentemente misturadas. Uma é a da relação entre países islâmicos e Ocidente, ${ }^{14} \mathrm{e}$ a outra é a da relação entre minorias muçulmanas e maiorias cristãs ou secularizadas nos países europeus. ${ }^{15}$ No primeiro caso, seria inevitável falar do colonialismo ocidental, que, porém, contrariamente a certa visão bastante comum, não tem nada a ver com as cruzadas, que podem ser vistas antes como uma reação à conquista islâmica de territórios até lá cristãos, como a chamada "Terra Santa", a Sicília, a Espanha ou os territórios do Império Romano do Oriente. A atitude dos cruzados é especular àquela dos conquistadores muçulmanos dessas regiões. Foi somente com a crescente influência europeia no Oriente Médio no século XIX, com a definitiva conquista inglesa da Índia (que compreende amplos territórios com maioria muçulmana, como os atuais Paquistão e Bangladesh) e com a expedição de Napoleão no Egito, que a atitude dos europeus perante os muçulmanos muda radicalmente (BILGRAMI 2012), passando de uma atitude de hostilidade, mas também de certo respeito (embora se trate do respeito tributado a um inimigo) a uma atitude de superioridade motivada com a primazia econômica e militar dos países europeus. Essa atitude de superioridade passa a marcar as relações entre europeus e muçulmanos no Oriente Médio como na Índia ou em outros lugares, inclusive na própria Europa. Segundo Akeel Bilgrami, isso ajudaria a explicar porque a maioria dos muçulmanos, embora não compartilhe a visão que os fundamentalistas têm do Islã, não se distancia abertamente deles ou até acaba votando nos partidos fundamentalistas. ${ }^{16}$ Para contrabalançar um pouco essa descrição bastante unilateral, que atribui a responsabilidade das atuais tensões entre mundo islâmico e mundo ocidental somente a esse, poder-se-ia acrescentar ao quadro o apoio que setores econômica e politicamente poderosos do mundo árabe, como a família real saudita, deram e ainda dão aos movimentos fundamentalistas, inclusive na Europa, ou até a grupos terroristas ativos no Ocidente, mas também nos próprios países muçulmanos. Ou ainda poder-se-ia mencionar a política francamente islâmica de vários governos, em particular, do governo turco de Erdoğan, que está conduzindo uma maciça ofensiva cultural e jurídica contra os setores laicos de seu país, impondo cada vez mais valores e normas de cunho religioso naquele que era o país mais secularizado da região. Nesse contexto, não poderemos ocupar-nos da questão de até que ponto esses fenômenos possam ser lidos como consequência do colonialismo europeu ou não apontem antes para conflitos culturais e de poder que são internos às sociedades em questão (como fica evidente no caso da Turquia), mas nos limitaremos a registrar que a situação vai 
muito além de um mero conflito de civilizações, como gostam de chamá-lo os ideólogos do anti-islamismo, mas também de uma mera reação anticolonialista, como defendem os críticos da política ocidental no Oriente Médio.

Ora, a questão da relação entre países muçulmanos e países ocidentais se sobrepõe àquela da atitude das minorias muçulmanas na Europa somente na medida em que tal atitude é influenciada também pelos acontecimentos no Oriente Médio ou na medida em que os muçulmanos europeus mantém relações estritas com seus países de origem e se recusam a identificar-se meramente como cidadãos de seus países de acolhida ou, no caso das segundas e terceiras gerações de imigrados, de nascimento. Não se trata de uma questão secundária. Há alguns anos, foi realizado um célebre estudo, que mostrou que muitos muçulmanos europeus não estão particularmente dispostos a integrar-se em seus países de chegada ou, no caso das novas gerações, de nascimento. ${ }^{17}$ À pergunta se eles se sentiam antes muçulmanos ou cidadãos de seus países uma esmagadora maioria responderam escolhendo a primeira opção: $81 \%$ na Grã-Bretanha (frente 7\% que diziam sentir-se primeiramente inglês), 69\% na Espanha (com apenas 3\% que se sentia espanhol), 66\% na Alemanha (frente 6\% que se sentia alemão), mas interessantemente na França, acusada habitualmente de laicismo exasperado e de islamofobia, o percentual dos que se sentiam primariamente muçulmanos desceu aos $46 \%$ e a dos que se sentem franceses subiu aos $42 \%$.

Esses dados alimentaram bastante o preconceito anti-islâmico e favoreceram partidos abertamente islamofóbicos como o UKIP britânico ou o francês Fronte Nationale, mas a mesma pesquisa mostrou outros dados interessantes que tornam o quadro mais complexo. A mesma questão obteve respostas semelhantes também em países islâmicos. No Paquistão 87\% se considera primariamente muçulmano e somente $6 \%$ paquistanês, na Jordânia as duas percentuais são respectivamente de 67 e 21\%, na Nigéria de 71 e 25\%. E quando a pergunta foi feita a cristãos, é verdade que na Europa se obtiveram resultados invertidos, mas nos EUA $42 \%$ declararam sentir-se antes cristãos do que americanos frente um $48 \%$ que se identifica primariamente como cidadão estadunidense. Na Alemanha a percentual dos que se identificam como cristãos antes que como alemães é de 33\% (contra um 59\% que se considera primariamente cidadão alemão), na Grã-Bretanha é de 24\% (contra 59\%), na já catolicíssima Espanha é de apenas $14 \%$ contra $60 \%$, e na França, pouco surpreendentemente, 14\% se identifica primariamente como cristão e $83 \%$ se sente primariamente francês. Então, parece que o problema da escassa identificação com a própria comunidade nacional não seja exclusivo do Islã e afete também o Cristianismo, particularmente em lugares onde prevalecem 
versões mais fundamentalistas, como nos EUA. ${ }^{18}$

Isso situa a questão da identificação dos muçulmanos europeus com os países nos quais vivem num contexto mais amplo, que inclui os cristãos, e levanta uma questão mais geral, a saber, a da lealdade cívica das pessoas particularmente religiosas, que é discutida também por Rousseau no Contrato Social: segundo o genebrino, estas pessoas não podem ser bons cidadãos, pois sempre anteporiam os ditames de sua religião às leis de seu país. ${ }^{19}$ Tratase obviamente de um juízo drástico, excessiva e insustentavelmente negativo, mas parece haver nele certo fundo de verdade, quando se considera a questão da objeção de consciência com base religiosa que leva médicos de hospitais públicos a não praticar abortos, ou farmacêuticos a não vender contraceptivos, ou funcionários públicos a não celebrar uniões homoafetivas nos países onde existem leis permitindo tudo isso. É legítimo que um funcionário público negue a um cidadão um direito garantido pela lei? Não teria o Estado aqui um bom argumento para demitir esse funcionário? Afinal, existem hospitais cristãos onde aqueles médicos poderiam atuar e outras profissões que esses crentes poderiam exercer sem ter que renunciar às próprias convicções religiosas.

Neste ponto, devemos concordar com os autores que afirmam que se exige dos muçulmanos o que (indevidamente) não se exige dos cristãos, a saber, que renunciem às posições mais radicais que sua religião os leva a assumir em relação às leis dos países ocidentais - por ex. quando não tratam as mulheres de maneira paritária. Por que impedir às mulheres muçulmanas de usar o véu (hijab) em público e não fazer o mesmo com as freiras católicas ou luteranas? Por que proibir, servindo-se do argumento da quiete pública, que os muezins chamem pelos alto-falantes das mesquitas para as orações cotidianas e não fazer o mesmo com os sinos das igrejas cristãs? Há, de fato, uma assimetria aqui, mas sua eliminação não deveria passar pela atribuição à minoria muçulmana do direito de impor suas visões na esfera pública como acontece com os cristãos, por ex. atribuindo-lhes o direito de aplicar a xaria, como já acontece em algumas regiões da Grã-Bretanha e, embora não oficialmente, da Alemanha; antes, são os cristãos que deveriam dar um passo atrás e renunciar a impor seus valores e suas normas ao restante da sociedade, para abrir espaço para outros valores e para normas comuns a todos: cristãos e muçulmanos, crentes e não crentes, indivíduos religiosos e indivíduos secularizados. ${ }^{20}$

O apelo para a "identidade cristã" dos países ocidentais, que é introduzido frequentemente neste contexto, não convence por várias razões. Em primeiro lugar, a maioria desses países se secularizou bastante e, apesar de ter ainda uma maioria de pessoas que se dizem cristãs (embora somente uma minoria frequente as igrejas regularmente), existem neles 
parcelas significativas de cidadãos que não são cristãos ou que não possuem religião nenhuma (em alguns países como a Holanda e a República Tcheca agnósticos e ateus são até a maioria). Em segundo lugar, a identidade cultural não é algo imutável, como a própria história desses países demonstra. Ela pode mudar e não há boas razões para defendê-la com iniciativas legais que visem oprimir outras identidades culturais presentes na sociedade ou proibir qualquer mudança. Em terceiro lugar, nas sociedades em questão prevaleceram, nos últimos setenta anos, uma visão de liberdade individual e uma concepção de democracia, que resultam incompatíveis com a ideia da submissão de todos os indivíduos a uma cultura ou religião dominante. Exigir, por exemplo, que todos os alunos das escolas públicas leiam a Bíblia em sala de aula, como acontece em várias prefeituras no Brasil, ${ }^{21}$ é sinal de absoluto desrespeito para com a liberdade individual e o caráter democrático da sociedade.

Por outro lado, e assim chego ao terceiro discurso, o do "laicismo estatal", justamente a visão de liberdade individual e a concepção de democracia, sobre as quais se sustentam as sociedades ocidentais contemporâneas, entram frequentemente em conflito com os valores de algumas religiões, como o Islã ou o próprio Cristianismo - e não somente em suas versões mais fundamentalistas. $\mathrm{O}$ exemplo mais clássico disso diz respeito à posição das mulheres no Islã: apesar das inegáveis diferenças de tratamento (já que nem em todas as sociedades muçulmanas as mulheres são obrigadas a usar a burqa ou o niqab, e somente em algumas se pratica a infibulação ou circuncisão feminina), é evidente que em geral se trata de uma posição de inferioridade em relação aos homens, do ponto de vista do exercício pleno dos direitos civis e políticos que as sociedades democráticas liberais garantem a todos os cidadãos independentemente de seu gênero. Na xaria, na maioria dos casos, o testemunho de um homem vale o de duas mulheres, por exemplo, ${ }^{22}$ e é difícil não ver nisso um caso evidente de afirmação de uma presumida superioridade masculina e de opressão feminina.

Isso evidentemente poderia justificar uma intervenção direta do Estado visando estabelecer a paridade de gênero - e de fato a justifica, quando se trata de proteger as mulheres das formas mais violentas de submissão por parte dos maridos, pais, irmãos etc., lembrando, contudo, que essa defesa é garantida independentemente da religião dos envolvidos: as leis contra a violência doméstica não se ocupam da origem teológica, cultural ou psicológica de tal violência, mas visam somente impedi-la ou reprimi-la. O Estado protege jovens muçulmanas da violência de sua família que não aceita sua independência ou seu namoro com um infiel, mas protege também mulheres maltratadas por maridos cristãos ou ateus, embora, devido à percepção capciosa e parcial por parte da opinião pública, as notícias 
concernentes esses casos provoquem menos debates das que dizem respeito às famílias muçulmanas. Da mesma maneira, o Estado intervém para garantir a saúde das crianças que precisam de transfusão de sangue, mas cujos pais são contrários por motivos religiosos a esse tratamento, mas faria a mesma coisa se os pais se recusassem a tratar o filho por razões ideológicas não religiosas, por exemplo, por acreditarem em alguma bizarra teoria da conspiração. ${ }^{23}$ Nesses casos, apesar das aparências, o que está em jogo são menos a liberdade religiosa e a particularidade cultural dos envolvidos, e antes os direitos fundamentais das mulheres ou das crianças em questão. ${ }^{24}$ Se houvesse uma religião que impusesse a realização de sacrifícios humanos, como, por exemplo, a asteca, ninguém - espero - acusaria de astecofobia e de ódio antirreligioso o Estado que proibisse tal prática.

As coisas se complicam, porém, quando se deixa o terreno da violência ou da ameaça à integridade física, para atingir o da possível violação da autonomia individual e da integridade psicológica. Nesse caso, é difícil estabelecer com certeza até onde uma pessoa aceita voluntariamente práticas ou costumes que podem parecer aos olhos de outrem como uma violação de sua autonomia individual, e é complicado fixar o momento a partir do qual é legítimo falar em imposição forçada, mas sem o uso da violência física e só através da pressão social ou psicológica. De novo, o caso mais discutido diz respeito à população europeia de religião islâmica, pois se trata da proibição na França não somente da burqa, mas até do véu para cabelos ou hijab. Cabe aqui distinguir dois níveis. Um é o da proibição relativa a meninas em idade escolar. Tal proibição, na realidade, não é especificamente voltada ao uso do véu, mas, mais em geral, ao uso ostensivo de símbolos religiosos, e se aplica também ao uso de cruzes, estrelas de Davi ou kippahs. Na intenção da lei, a escola francesa representa um lugar de educação cívica e republicana que visa formar cidadãs e cidadãos em espírito de plena igualdade jurídica e não pode ser marcado por símbolos que, pelo contrário, acentuam as diferenças - em particular os que sinalizam uma submissão da mulher ao homem. Ora, essa aplicação da lei ao caso do véu foi criticada por atribuir a esta peça um significado religioso que, por si, ela não possui e por considerá-la símbolo de opressão feminina. Sobre o primeiro ponto, cabe lembrar que em muitas culturas, inclusive cristãs, as mulheres usam véus ou cobrem seus cabelos. Na própria França, na Córsega ou no Sul, isso era bastante comum até pouco tempo atrás, pelo menos entre mulheres de idade. Enquanto é correto identificar um homem com uma kippah ou uma mulher com uma cruz no pescoço como judeu e cristã, respectivamente, o fato de uma mulher usar um véu no cabelo não justifica identificá-la automaticamente como muçulmana. Sobre o segundo ponto, seria necessário discutir sobre o que se entende aqui por opressão feminina. Tal atitude se manifesta somente em impor a uma 
mulher que esconda seu cabelo ou seu rosto atrás de um véu? Penso, por exemplo, nos uniformes escolares de países como o Chile ou o Japão que parecem ter a finalidade de estimular o imaginário erótico masculino. Ou na pressão social para usar roupa justa que exalte as formas do corpo - sempre de maneira a agradar o olhar e a fantasia dos homens. Claro que devemos diferenciar entre os dois casos: a menina muçulmana que se recuse em usar o véu ou outro vestiário considerado apropriado pela sua família ou comunidade corre o risco de ser excluída delas ou até de ser vítima de violência física, enquanto a menina secularizada que prefira usar roupa confortável e fora da moda corre, no máximo, o risco de ser vítima da ironia das colegas ou de não encontrar tão facilmente um namoradinho. Em geral, existem diversos tipos de pressão que, por mais que sejam condenáveis, não possuem a mesma gravidade e representam graus diferentes de violação da autonomia e da personalidade da mulher - algo que certas feministas tendem a esquecer. ${ }^{25}$ Por outro lado, se a intenção da proibição do véu for mesmo a preocupação para com a submissão das mulheres e a violação do princípio da igualdade dos alunos enquanto cidadãos, seria mais coerente impor o uso de um uniforme escolar (naturalmente não de um como os das chilenas ou japonesas supracitadas).

Ainda mais complexo é o caso das mulheres adultas que usam o véu, em particular das estudantes universitárias ou das mulheres que usam burqa ou niqab, pois nesse caso, diferentemente daquele das crianças, deve-se pressupor seu consenso informado e consciente de pessoas autônomas e, portanto, a proibição do uso do véu nas universidades ou da burqa e do niqab em público, inclusive na rua, parece estar em contradição com os mesmos valores de liberdade individual que tal norma deveria salvaguardar. É evidente que podemos estar perante uma escolha formalmente voluntária que é, na realidade, o fruto da manipulação e da pressão exercidas pela família e pela comunidade religiosa ou cultural destas mulheres, que, provavelmente, foram educadas desde a infância a submeterem-se aos homens de casa (pais, irmãos, cunhados, maridos e até filhos), a aceitarem sua inferioridade em relação a eles e a esconderem-se do olhar masculino, para não serem consideradas mulheres imorais e disponíveis, que não só não merecem respeito, mas até merecem ser assediadas sexualmente. Nestas condições é difícil falar em escolha livre e autônoma. Mas não consigo imaginar como seja possível atribuir a essas mulheres maior autonomia através da proibição de sua roupa tradicional. Não somente o resultado será, provavelmente, o oposto do desejado, tirando-as da rua e confinando-as em suas casas (como, de fato, está acontecendo na França), mas é normativamente questionável atribuir ao Estado o poder de decidir quem esta agindo de forma 
autônoma e quem não, se excetuarmos o estabelecimento do limite artificial da maioridade, que, contudo, representa um mal necessário para evitar responsabilizar excessivamente as crianças.

Existem inúmeras formas de educação opressiva que tendem cancelar a autonomia da criança e acabam criando pessoas manipuladas e submissas - particularmente no caso de famílias fortemente religiosas que impõem às crianças seu credo, seus valores e suas normas. Por que uma mulher muçulmana acostumada desde a infância a usar o véu ou o niqab deveria ser considerada menos autônoma que um homem cristão no qual foi inculcada desde a infância a ideia de que a única forma de vida aceitável é aquela que se conforma ao ditado bíblico e que qualquer outra forma de vida é pecado e não merece respeito? A educação familiar é geralmente fonte de preconceitos antes do que educação ao pensamento autônomo. Claro que existem tipos de educação que fomentam mais preconceitos ou que criam sujeitos menos autônomos que outras, mas é questionável que o Estado tenha o direito de decidir por lei quais tipos de educação familiar são aceitáveis e quais não. O que ele pode e deve fazer é opor a esse tipo de educação familiar uma educação pública que confronte os estudantes com modelos alternativos e os ajude a desenvolver aquela capacidade crítica que suas famílias talvez não lhes deem sequer a possibilidade de formar.

Isso, contudo, exige por parte do Estado uma atitude que não é simplesmente de indiferença perante as diversas crenças religiosas, mas que pode às vezes entrar em conflito com elas. Conflitos deste tipo se deram e se dão, por exemplo, no caso do ensino do evolucionismo nos EUA ou no caso da educação sexual ou das campanhas para a tolerância da diversidade sexual no Brasil. Esses casos mostram que, longe de serem discriminados pela sociedade secularizada, os cidadãos cristãos destes países gozam um privilégio que não é concedido aos outros, a saber, a de servir-se de sua religião como desculpa para opor-se ao ensino de teorias e ideias que consideram incompatíveis com suas crenças. Se um grupo de pais tentasse impor que nas aulas de geografia fosse ensinada a teoria de que a Terra é chata, pois eles estão convencidos disso, ou se eles tentassem impor que em lugar da astronomia fosse ensinada a astrologia, nenhuma autoridade escolar ou política levaria a sério tais pedidos, por mais forte que seja a convicção dessas pessoas relativamente à forma do planeta ou à cientificidade da astrologia. Contudo, quando se exige que o criacionismo seja ensinado ao lado do evolucionismo, esse pedido é levado a sério, embora o fundamento dele seja o mesmo, a saber, uma convicção pessoal dos pais envolvidos, que não corresponde à realidade histórica e científica. Da mesma maneira, os pais de meninas de religião muçulmana podem pedir que suas filhas sejam exoneradas das aulas de educação física para não serem obrigadas 
a usar roupas que consideram imoral, mas o pedido de isenção seria recusado se os pais o motivassem com a convicção de que a educação física é inútil ou faz mal às crianças, ou de que sua ideologia política os leva a considerá-la uma forma de treinamento para a futura exploração no mercado capitalista de trabalho.

As religiões gozam, repito, de uma série de privilégios que vão muito além do mero direito de expressão ou de profissão religiosa. Retirar tais privilégios não significa, então, atentar a este direito, mas antes reestabelecer uma plena igualdade entre cidadãos religiosos e não religiosos. Essa é a convicção que está atrás da visão de um Estado laico, que não é a mesma coisa de um Estado laicista. Um Estado laico é um Estado que leva a sério o princípio de neutralidade religiosa e ideológica e, portanto, não garante nenhum privilégio especial a nenhuma religião ou ideologia, considerando que a crença nessas últimas constitui um fato privado que não pode interferir no estabelecimento de regras comuns de convivência e de políticas públicas que tratem todos os cidadãos como sujeitos iguais do ponto de vista jurídico. Um Estado laicista seria um Estado hostil à religião e à sua expressão não somente pública, mas inclusive privada. Um Estado laico pode ou até deveria prever o ensino da religião em seu currículo escolar, desde que isso signifique apresentar as diferentes religiões de maneira neutra e científica, e não deixar espaço somente a uma doutrina específica como o cristianismo - que é o que acontece hoje. Um Estado laicista nem sequer admitiria esta possibilidade. Por isso, falar em laicismo ou em ideologia secularista, como fazem alguns autores (inclusive Charles Taylor), representa uma redução caricatural da ideia de laicidade que repete de maneira especular a redução de toda e qualquer forma de religiosidade ao fundamentalismo. ${ }^{26}$

Um Estado laico deveria percorrer um caminho - impérvio e nada fácil - que lhe permita não cair nas armadilhas representadas pelos modelos atualmente dominantes, a saber, o do Estado teocrático, o do Estado confessional, o do Estado pluralista e do Estado laicista, dos quais encontramos exemplos respectivamente na Arábia Saudita, no Brasil, na GrãBretanha e na França atuais. Sobre o caráter teocrático da Arábia Saudita, não preciso dizer nada. O caráter confessional do Brasil se manifesta na presença maciça do cristianismo na esfera política e na violação continuada da laicidade do Estado, da qual mencionei alguns exemplos, aos quais poderia ser acrescentado o número crescente de iniciativas políticas visando impor uma visão cristã fundamentalista ao resto da sociedade, como no caso da leitura obrigatória da Bíblia nas escolas introduzida em muitas prefeituras, ou como no caso da definição de uma figura jurídica central como a da família com base no ditado bíblico e 
não na realidade social, ou como no caso da marcação de território realizada por meio de totens, portais e monumentos proclamando que "a cidade X é do Senhor Jesus Cristo", 27 no mais absoluto desprezo dos concidadãos que não concordam com esta visão ou por seguirem outra religião ou por serem ateus. A Grã-Bretanha concede, em nome do pluralismo religioso, uma série de privilégios que acabam ameaçando seriamente o princípio da igualdade dos cidadãos perante a lei, abrindo inúmeras exceções motivadas religiosamente. O resultado é uma sociedade fragmentada, na qual as diferentes comunidades religiosas tendem a fechar-se cada vez mais em si mesmas, conforme um modelo de multiculturalismo-mosaico. A França, na medida em que adota leis como a proibição do véu nas universidades ou da burqa e do niqab na rua, está tomando uma posição laicista e não meramente laica.

Sei que se trata de alcançar um equilíbrio complicado entre os extremos e não tenho a pretensão e muito menos a capacidade de indicar uma solução. Contudo, considero fundamental que as questões a serem enfrentadas na busca deste equilíbrio sejam tratadas de maneira neutra e objetiva, evitando sensacionalismos e atitudes emocionais como as que até agora caracterizaram o debate sobre o Islã na Europa - tanto num campo como no outro, como vimos. Ao apontar neste meu texto para alguns dos erros e mal-entendidos mais comuns em relação à questão de como devemos enfrentar o tema da presença da religião na esfera pública e na politica, espero ter contribuído um pouco para elevar o debate àquele patamar de objetividade que é necessário para encontrar soluções duradouras. 


\section{Notas:}

${ }^{1}$ Este artigo é o texto de uma palestra que ministrei no II Encontro de Ética e Filosofia Política da UFRN, que aconteceu em maio de 2015 e teve como tema "A religião em questão". Resolvi não modificá-lo e manter o caráter de um texto pensado para ser falado. As observações mais estritamente acadêmicas se encontram nas notas de rodapé, que acrescentei para a publicação.

${ }^{2}$ As violências religiosas da Índia são objeto de muitos livros de ficção (como Midnight's Children de Salman Rushdie) e de textos científicos (como Identity and Violence de Amartya Sen).

${ }^{3}$ Também no preâmbulo da Constituição Brasileira de 1988 há uma invocação à proteção de Deus, que, contudo, o STF não julgou ameaçar o caráter laico do Estado - o que é bastante questionável (ver a documentação relativa à sentença do STF em http://redir.stf.jus.br/paginadorpub/paginador.jsp?docTP=AC\&docID=375324).

${ }^{4}$ Assistimos recentemente a verdadeiros pogroms contra os seguidores das religiões afro-brasileiras, muitas vezes no silêncio gritante das autoridades políticas e policiais, quando não com certo consentimento delas. Como no caso do juiz Eugênio Rosa de Araújo da $17^{\text {a }}$ Vara Federal do Rio que afirmou que cultos afro-brasileiros como Umbanda e Candomblé não são religiões e, portanto, não gozam da proteção contra intolerância religiosa como as "verdadeiras" religiões (http://www1.folha.uol.com.br/poder/2014/05/1455758-umbanda-e-candomblenao-sao-religioes-diz-juiz-federal.shtml). Metade dos terreiros no Rio foi já alvo de violências por parte de fundamentalistas cristãos (http://oglobo.globo.com/sociedade/levantamentos-mostram-perseguicao-contrareligioes-de-matriz-africana-no-brasil-13550800), muitas vezes por parte de traficantes evangélicos (e aqui caberia um estudo especial sobre a questão de como eles conciliam sua fé cristã com a violência brutal que exercem a cada dia - mas afinal a história está repleta de violências bárbaras realizada em nome de Cristo e à revelia de sua mensagem de amor universal).

${ }^{5}$ Exemplar neste sentido a pesquisa da fundação Perseu Abramo: http://www.http.com//www3.fpabramo.org.br/o-que-fazemos/editora/teoria-e-debate/edicoes-

anteriores/intolerancia-diversidade-sexual. Apesar do vitimismo com o qual vários cristãos, começando pelo papa atual, lamentam a presumida discriminação da qual eles seriam vítimas em nossas sociedades presumidamente secularizadas, até agora as verdadeiras vítimas - no sentido real de: vítimas de violência física foram os crentes de outras religiões (em particular os seguidores dos cultos afro-brasileiros) e os ateus.

${ }^{6}$ Em seu livro The New Religious Intolerance, Nussbaum acusa de maneira bastante genérica os europeus de intolerância religiosa contra os não cristãos, em particular, os muçulmanos (NUSSBAUM 2012). No presente contexto, não posso entrar numa análise detalhada dos seus argumentos, mas gostaria de chamar a atenção dos eventuais leitores desse livro para a parcialidade dos exemplos escolhidos pela autora (só negativos) e para o fato de que ela parece não ter compreendido minimamente o que está verdadeiramente em jogo no debate europeu sobre o Islã, que não é um debate de caráter religioso ou doutrinário e que não se interessa pelos conteúdos teológicos do Islã, mas pelas consequências sociais e políticas da presença de amplas minorias entre os cidadãos ou os imigrados de religião muçulmana em sociedades pluralistas e/ou secularizadas, que vivem já faz muitas décadas com base em valores que tais minorias não somente não aceitam, mas combatem ativamente. Nussbaum escolhe de maneira absolutamente parcial exemplos que fazem de todo e qualquer muçulmano europeu uma vítima da intolerância, e desconsidera completamente os exemplos, nos quais a intolerância é manifestada por pessoas de religião muçulmana (inclusive de forma violenta).

${ }^{7}$ Trata-se de Peter Carey, Michael Ondaatje, Francine Prose, Teju Cole, Rachel Kushner e Taiye Selasi. Fonte: http://www.nytimes.com/2015/04/27/nyregion/six-pen-members-decline-gala-after-award-for-charliehebdo.html? $\mathrm{r}=1$

${ }^{8}$ Uma célebre capa do jornal, por ex., mostrava as três pessoas da Trindade cristã praticando atos sexuais entre si e provocou os legítimos protestos da igreja católica francesa e de outras igrejas cristãs; o mesmo aconteceu com a comunidade judaica, quando as capas ou os desenhos atacaram sua religião, e nunca faltavam no jornal capas e caricaturas que gozavam de forma vulgar e pesada da extrema direita como da extrema esquerda, ou de homens políticos franceses e europeus.

${ }^{9}$ Sobre este ponto, permito-me remeter a PINZANI 2008. 
${ }^{10}$ O adjetivo "islamista" é outra coisa que "islâmico" e se refere a certa ideologia fundamentalista inspirada no Islã.

11 Pela mesma razão, é necessário reconhecer os motivos ideológicos dos atos violentos dos neo-nazistas e indagar as causas que levam jovens europeus a tornar-se tais.

${ }^{12}$ Veja-se os dados nos relatórios acessíveis no site http://www.antisemitisme.fr/.

${ }^{13}$ Refiro-me à série de assassinados praticada pelo grupo de extrema direita alemão NSU, formado, contudo, por três pessoas e cujo caráter islamo- e xenófobo se tornou claro somente quando se descobriu que os homicídios tinham sido realizados pelas mesmas pessoas, já que essas nunca reivindicaram tais crimes, como os grupos terroristas costumam fazer.

${ }^{14}$ Sobre este ponto ver entre outros TOURAINE 2011 e APPIAH 2012.

${ }^{15}$ Sobre este ponto ver entre outros GÖLE 2011 e ALLIEVI 2012.

16 “A maioria dos muçulmanos comuns é dividida entre seu desgosto para com as visões absolutistas [termo que Bilgrami prefere a "fundamentalistas" - A.P.] de sua religião e de suas sociedades, por um lado, e, por outro, seus sentimentos de profunda desconfiança e ressentimento contra forças que, na percepção deles, por muito tempo lhes foram hostis e estranhas, em diferentes formas de colonialismo, e que frequentemente apoiaram os absolutistas [fundamentalistas] quando isso estava no interesse de seus planos políticos" (BILGRAMI 2012, 480).

${ }^{17}$ Fonte: $\quad$ http://www.pewglobal.org/2006/07/06/muslims-in-europe-economic-worries-top-concerns-aboutreligious-and-cultural-identity/

${ }^{18}$ Seria interessante ver os resultados de uma pesquisa análoga aqui no Brasil, mas não conheço nenhuma que tenha sido efetuada até agora.

${ }^{19}$ Contrato Social, livro IV, capítulo VIII “Da religião civil”".

${ }^{20}$ Em outras palavras: Ao mesmo tempo em que se ouvem na esfera pública contínuas admoestações contra os perigos de uma islamização da sociedade europeia e de uma crescente influência do fundamentalismo islâmico, esquecem-se os frequentes fenômenos de ingerência pesada por parte das igrejas cristãs na política dos vários países europeus e americanos e a adoção por parte de políticos cristãos de leis e medidas que obedecem aos ditames de sua religião, mas ferem o princípio da neutralidade do Estado e até a igualdade jurídica dos cidadãos. Assim, por ex., na Itália foi introduzida, em consequência de uma maciça campanha por parte do Vaticano, uma lei que impõe que os médicos mantenham artificialmente em vida pacientes em estado vegetativo também quando haja uma precedente declaração escrita por parte destes últimos que disponha o desligamento das maquinas para casos deste tipo; sempre na Itália, e sempre sob a pressão da igreja católica, o Estado segue não reconhecendo nenhum tipo de união estável que não o casamento entre homem e mulher, em flagrante contradição com o direito europeu, uma vez que o Estado italiano se recusa a reconhecer legalmente os casamentos homoafetivos e as uniões estáveis heterossexuais realizados em outros países. Tudo isso, sem esquecer os mencionados casos de violação do princípio da laicidade do Estado registrados no Brasil.

21 Só para citar alguns exemplos: http://www1.folha.uol.com.br/cotidiano/2014/07/1486584-camara-aprovaleitura-obrigatoria-da-biblia-em-escolas-de-nova-odessa-sp.shtml,

http://dc.clicrbs.com.br/sc/noticias/noticia/2015/04/justica-suspende-lei-que-obriga-biblia-nas-escolas-deflorianopolis-4743935.html, http://lunatenorio.jusbrasil.com.br/noticias/124281427/projeto-de-lei-em-fortalezapropoe-leitura-obrigatoria-da-biblia-em-escolas-publicas-e-privadas http://www.araguainanoticias.com.br/noticia/988/leitura-biblica-sera-obrigatoria-nas-escolas-municipais-dearaguaina.html, http://www.paramocinhos.com.br/2015/07/vereador-cria-projeto-que-obriga.html

${ }^{22}$ Uma justificativa disso se encontra em: http://sunnahonline.com/library/fiqh-and-sunnah/24-library/womenand-islam/419-why-two-women-witnesses Para uma lista dos países, nos quais o testemunho de uma mulher vale a metade daquele de um homem ver: https://en.wikipedia.org/wiki/Status_of_women's testimony_in_Islam 


\begin{abstract}
${ }^{23}$ Mais recentemente, um tribunal alemão decidiu que a circuncisão masculina assim como ela é praticada nos ritos judaicos e muçulmanos representa uma ameaça à saúde das crianças e uma violação injustificada de sua integridade física, uma vez que tal operação é praticada de forma ritual, sem os necessários cuidados médicos (e de fato houve muitos casos - inclusive graves - de infecção entre as crianças). Portanto, o tribunal proibiu esta prática.
\end{abstract}

${ }^{24}$ Por isso, os mesmos países que proíbem a circuncisão ou impõem a transfusão de sangue nos casos mencionados, aceitam em geral o abate conforme o ritual halal ou kosher, embora isso leve a um maior sofrimento dos animais - e não faltam movimentos animalistas que exigem a proibição dessas formas de abate, não por islamofobia ou antissemitismo, mas por uma legítima preocupação para com os animais.

${ }^{25}$ As feministas que comparam o uso do véu à pressão social para que as mulheres tenham sempre um belo aspecto, sejam bem vestidas, magras, sem rugas etc., têm razão somente em parte, pois o risco de tais comparações é o de encobrir o diferente tipo de violência e de pressão dos quais são vitimas as mulheres muçulmanas.

${ }^{26}$ Do mesmo modo, dever-se-ia distinguir entre ateus e ateístas, ou seja, entre indivíduos que, simplesmente, não acreditam na existência de uma divindade e indivíduos que tentam convencer os demais da absurdidade da crença em um deus, como Richard Dawkins. Os primeiros fazem de sua convicção uma questão privada e não tentam impô-la aos demais, enquanto os segundos acabam repetindo os erros do tipo de crentes por eles criticado, a saber, dos crentes que pretendem impor sua crença aos outros.

${ }^{27} \mathrm{O}$ caso mais conhecido, por causa das polêmicas suscitadas, é o de Sorocaba (SP) (cf: http://g1.globo.com/saopaulo/sorocaba-jundiai/noticia/2013/06/mp-quer-retirada-imediata-de-totem-religioso-da-entrada-de-sorocabasp.html ), mas pessoalmente vi placas deste tipo em muitas cidades (por ex. Urubici, na Serra Catarinense). 


\section{Referências bibliográficas:}

ALLIEVI, Stefano. Reactive identities and Islamophobia: Muslim minorities and the challenge of religious pluralism in Europe. In: Philosophy and Social Criticism, 38/4-5, 2012, 379-387.

APPIAH, Kwame A. Misunderstanding cultures: Islam and the West. In: Philosophy and Social Criticism, 38/4-5, 2012, 425-433.

BILGRAMI, Akeel. Islam and the West: Conflict, Democracy, Identity. In: Philosophy and Social Criticism, 38/4-5, 2012, 477-483.

GÖLE, Nilüfer. The public visibility of Islam and European politics of resentment: The minarets-mosques debate. In: Philosophy and Social Criticism, 37/4, 2011, 383-392.

NUSSBAUM, Martha C. The New Religious Intolerance. Overcoming the Politics of Fear in an Anxious Age. Cambridge (MA): Belknap Press, 2012.

PINZANI, Alessandro. Identidade coletiva, culturas e secessão. In: MORTARI, Cezar (org.). Anais do V Colóquio Internacional Principia (2007). Florianópolis: NEL, 2008, 240-259.

TOURAINE, Alain. Many cultures, one citizenship. In: Philosophy and Social Criticism, 37/4, 2011, 393-399. 